\title{
Renewable Energy Policies: Bibliometric Review and Policy Implications
}

\author{
Valeria ANNIBALDI ${ }^{1}$, Alessia CONDEMI ${ }^{2}$, Federica CUCCHIELLA $^{3 *}$, \\ Massimo GASTALDI ${ }^{4}$, Marianna ROTILIO ${ }^{5}$ \\ ${ }^{1-4}$ Department of Industrial and Information Engineering \& Economics, University of L'Aquila, \\ Piazzale Pontieri, Roio, L'Aquila, Italy \\ ${ }^{5}$ Department of Civil, Construction-Architectural and Environmental Engineering, University of L'Aquila, \\ Via G. Gronchi n. 18, L'Aquila, Italy
}

\begin{abstract}
The energy policies of the Union States should promote energy security, energy efficiency, decarbonisation, research, innovation and competitiveness. In addition, over the last few years, the research on these topics has significantly enlarged and received increasing attention from policy makers interested in focusing and accelerating socio-technical systems towards sustainability. The scientific productivity of European Union States about the Renewable Energy policies is here evaluated. For each selected policy, positive and critical aspects are noted to assess the possibility of any changes that could lead to an increase in the renewable energy exploitation.
\end{abstract}

Keywords - Bibliometric review; Contract for Difference; European Union; FIP; FIT; Green Certificate; Renewable energy support; SDG 7

\section{INTRODUCTION}

Nowadays, every sector of contemporary life requires the use of energy, which moves the "wheel of civilization by supporting all the needs of society" [1], [2]. The energy use requires a solution to create an alternative to the so-called non-renewable energies, that are polluting and increasingly scarce [3], [4]. It is now known that energy systems are taking a fundamental role in the mitigation of climate change [5], [6]. Several studies carried out in Europe show that extreme climate events are increasingly frequent [7], [8].

In this regard, the European Union since the 1990s has led Member States to adopt energy policies that promote the use of renewable energy in national territories [9], [10].

In particular, the energy policies of the Union States should encourage energy security, energy efficiency, decarbonisation, research, innovation and competitiveness. Therefore, the main objective of the Member States governance mechanism should be that aimed at allowing the achievement of specific objectives, initially by 2020, then from 2021 to 2030, up to a zero-climate impact for Europe by 2050. Firstly, the regulatory reference point for EU states is the "Climate and Energy Package 2020" which consists in compulsory rules aimed at ensuring that the EU target will be reach by 2020 . Individual objectives for each member state of European Union have been set in order to achieve this goal. These objectives were

\footnotetext{
* Corresponding author.

E-mail address: federica.cucchiella@univaq.it

C2020 Valeria Annibaldi, Alessia Condemi, Federica Cucchiella, Massimo Gastaldi, Marianna Rotilio.

This is an open access article licensed under the Creative Commons Attribution License (http://creativecommons.org/

licenses/by/4.0), in the manner agreed with Sciendo.
} 
commensurate with: the national income, the initial situation of the various countries, the size of the territory and the population density per $\mathrm{km}^{2}$.

Each Member State has its own objectives to be achieved by 2020 and had to present a National Energy Plan containing the energy policies that are intended to be implemented on the national territory, transposing the directives and regulations contained in the Climate and Energy Package 2020 of the EU. National strategies and the results achieved have been studied, criticized and discussed by researchers [11]-[16]. The analysis of historical data and future scenarios is fundamental to help decision makers to understand strengths and weaknesses, synergies and bottlenecks of the possible energy policies interventions [17].

According to [18] the success of energy efficiency policy depends on the simultaneous implementation of several policy instruments, the coordination of several policy instruments and the correct implementation sequence of policy instruments.

The aim of this paper is to analyse in which countries there has been a strong focus on the issue of energy policies through a bibliometric analysis. Then, the attention will focus on the policies of these States. For each policy, positive and critical issues will be noted to assess the possibility of any changes that could lead to an increase in the renewable energy utilization.

A greater understanding of energy policies of European countries is useful for policy makers to understand the strengths and weaknesses of energy policy interventions. In fact, policy makers must consider the requests from the international community and, at the same time, they have to deal with national priorities.

The paper is organized as follows: in section II a bibliometric analysis based on Scopus is presented to identify the most sensitive member countries of the European Union in publishing researches regarding renewable energy; in section III the results achieved by the main Member States in activities regarding renewable energy policies will be analysed, based on the official data published by Eurostat; then, the results will be compared and analysed in sections IV and V. The final conclusions close the paper.

\section{Bibliometric ANAlysis}

In order to evaluate the number of publications for each European Union member country, a bibliometric analysis is carried out on the aforementioned topic. Bibliometrics has the main purpose of analysing bibliographic references by extrapolating the quantitative relationships between the different documents through the use of citational and multidisciplinary bibliographic databases. This study uses, as bibliographic databases, the Scopus ones to recover documents from 2010 until March 2020. The documents were selected by querying to the database the following keywords: "feed in tariff" OR "feed in premium" OR "green certificate" OR "green certification" OR "renewable portfolio standard" OR "renewable public support” OR “investment grant” OR "quota obligation system” AND Austria OR Italy OR Belgium OR Latvia OR Bulgaria OR Lithuania OR Croatia OR Luxembourg OR Cyprus OR Malta OR Czechia OR Netherlands OR Denmark OR Poland OR Estonia OR Portugal OR Finland OR Romania OR France OR Slovakia OR Germany OR Slovenia OR Greece OR Spain OR Hungary OR Sweden OR Ireland OR Europe OR “United Kingdom”.

So, the aforementioned keywords were searched in article titles, abstracts, keywords in the time span from 2010 until March 2020 belonging to Scopus database. 
The initial search resulted in 804 documents, reduced to 582 after removing any document not classified as article and review. So, the final number of analysed publications is 582 , inclusive of 508 articles and 74 reviews.

Among the 582 publications examined, it is interesting to identify the number of publications by each Member State. Thanks to the Scopus databases, each publication was assigned to a country using the corresponding authors' address. The number of publications divided its population size represents a scientific productivity indicator, which provides a purely quantitative information without considering the impact that a publication has on the reference scientific community.

Fig. 1 indicates EU Member States according to number of publications adjusted for population.

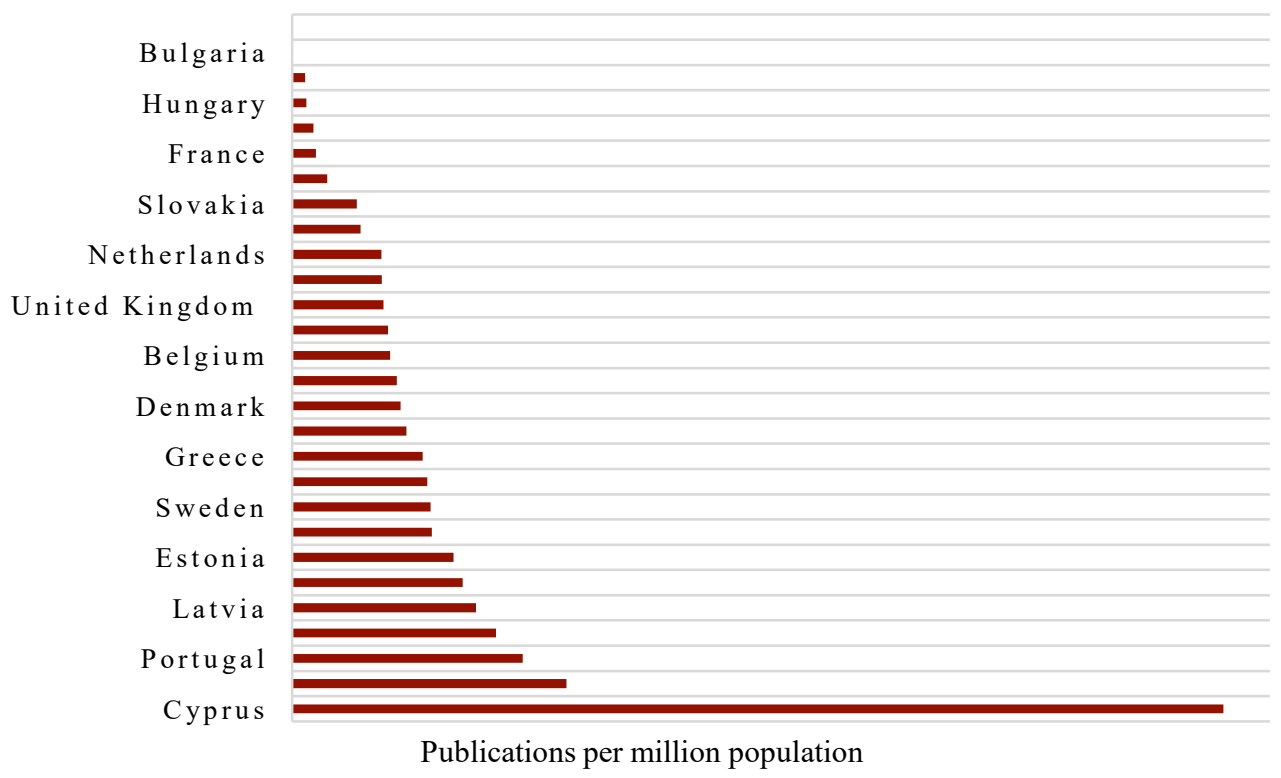

Fig. 1. Number of publications per EU Member States adjusted for population.

Cyprus emerged as the leader in terms of number of publications standardized to population size. Countries such as Lithuania, Portugal, Ireland and Latvia have very similar values in terms of publications per million population.

Neglecting the differences in the population sizes among the countries, the number of publications in absolute value was employed as an indicator for evaluating in which countries there has been a strong focus on the issue of energy policies. However, when the number of publications is not standardized to population size, other countries like Germany, United Kingdom and Spain became leaders in the analysis.

Fig. 2 shows the total number of publications in absolute value for each member country of the European Union (also considering United Kingdom) for the 2010-2020 decade. 


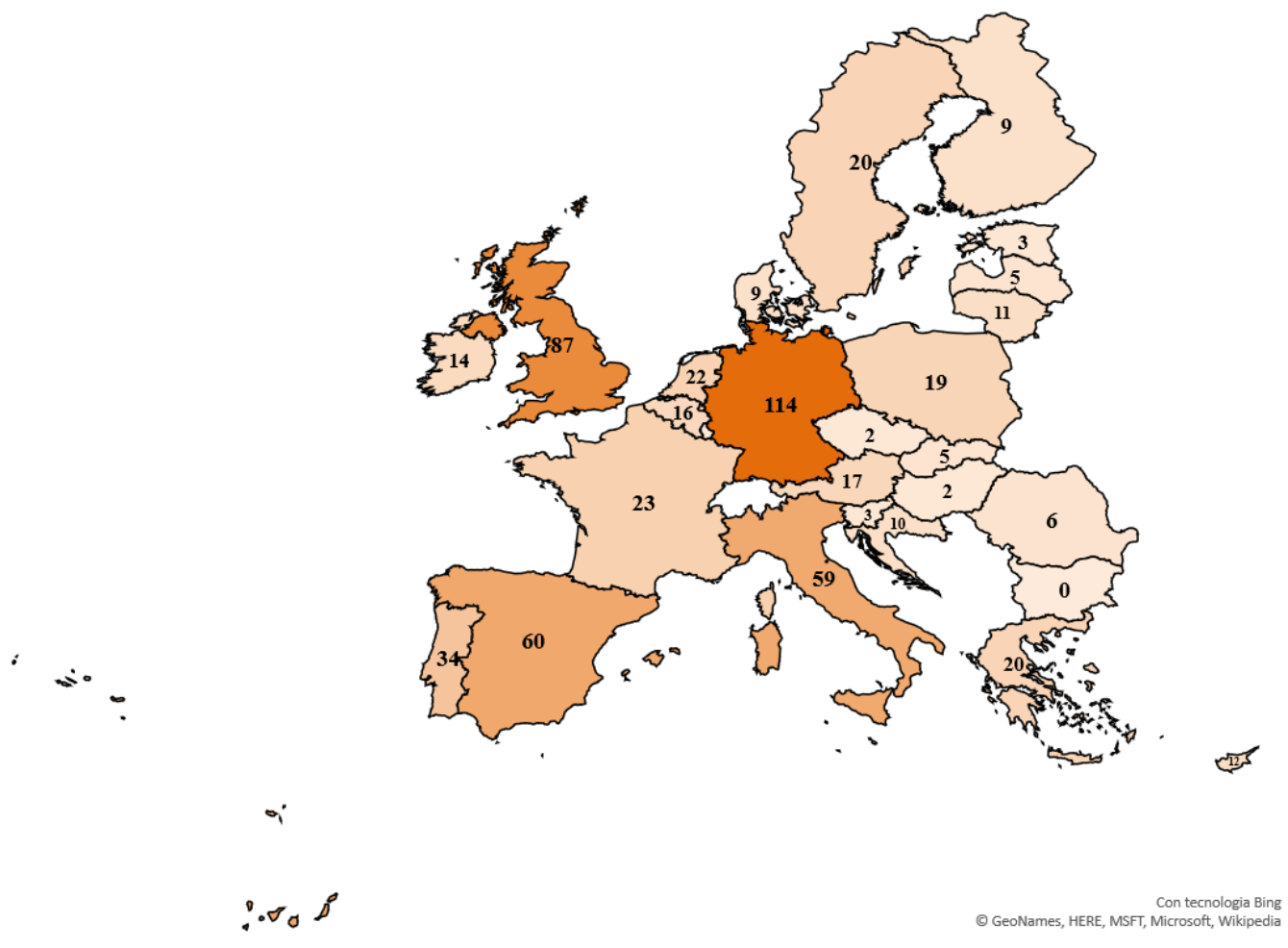

Fig. 2. Total number of publications per EU Member State.

Germany is the state with the highest number of publications (114) on the topic of interest during the 2010-2020 decade, followed by Great Britain (87), Spain (60) and Italy with its 59 publications. Portugal, France and Netherlands have respectively 34, 23 and 22 publications. Instead, Greece, Sweden, Poland, Austria, Belgium, Ireland, Cyprus, Lithuania and Croatia have between 10 (Greece and Sweden) and 20 (Croatia). Countries with fewer than 10 publications are Denmark, Finland, Romania, Latvia, Slovakia, Estonia, Slovenia, Czech Republic, Hungary and Malta. Bulgaria and Luxembourg have zero publications.

In Table 1, for each country, the historical series of publications in the decade of analysis is reported. Since the analysis is until March 2020, the number of publications in this year is significantly low, in particular it ranges between 0 and 3 (Italy).

The most productive years for Germany are 2016 and 2019 with 16 publications but also in the remaining years the number of annual publications is remarkable with a minimum of 6 publications in the year 2010. The number of publications of Great Britain grows in the early years, starting from 4 publications in 2010, reaching the peak in 2014 with 12 publications and then decreasing in the last five years reaching 5 publications in 2019. Spain and Italy have the maximum productivity in 2015 with 10 and 14 publications respectively. Instead, the remaining countries have a significantly lower number of publications with a maximum of 7 annual publications. In particular, Slovakia, Estonia, Slovenia, Czech Republic, Hungary and Malta have only one publication published in each year.

The 2015 is the most productive year with 78 publications, followed by 2017 with 75 ones. From 2010 to 2015 the total number of publications increased from 30 publications in 2010 
to 78 in 2015 . From 2015 to 2017 the total number of publications is quite high and then decreased in the period 2018-2019.

Table 1. Annual Publications Per EU Member States

\begin{tabular}{|c|c|c|c|c|c|c|c|c|c|c|c|c|}
\hline \multirow[b]{2}{*}{ Country } & \multicolumn{12}{|c|}{ Year } \\
\hline & 2010 & 2011 & 2012 & 2013 & 2014 & 2015 & 2016 & 2017 & 2018 & 2019 & 2020 & Tot \\
\hline Germany & 6 & 9 & 8 & 7 & 10 & 14 & 16 & 15 & 12 & 16 & 1 & 114 \\
\hline UK & 4 & 7 & 11 & 11 & 12 & 10 & 9 & 8 & 8 & 5 & 2 & 87 \\
\hline Spain & 4 & 4 & 6 & 3 & 9 & 10 & 6 & 6 & 7 & 5 & 0 & 60 \\
\hline Italy & 1 & 3 & 5 & 7 & 8 & 14 & 5 & 9 & 1 & 3 & 3 & 59 \\
\hline Portugal & 1 & 5 & 6 & 4 & 3 & 3 & 2 & 3 & 3 & 3 & 1 & 34 \\
\hline France & 0 & 1 & 0 & 1 & 1 & 7 & 2 & 3 & 5 & 2 & 1 & 23 \\
\hline Netherlands & 1 & 1 & 1 & 1 & 3 & 1 & 7 & 1 & 2 & 3 & 1 & 22 \\
\hline Greece & 1 & 1 & 4 & 3 & 1 & 1 & 3 & 2 & 0 & 4 & 0 & 20 \\
\hline Sweden & 4 & 1 & 1 & 2 & 0 & 3 & 4 & 2 & 1 & 2 & 0 & 20 \\
\hline Poland & 0 & 1 & 0 & 1 & 3 & 2 & 3 & 5 & 1 & 3 & 0 & 19 \\
\hline Austria & 2 & 3 & 2 & 2 & 3 & 1 & 0 & 1 & 2 & 1 & 0 & 17 \\
\hline Belgium & 0 & 0 & 1 & 1 & 3 & 1 & 0 & 4 & 3 & 2 & 1 & 16 \\
\hline Ireland & 1 & 1 & 2 & 3 & 1 & 2 & 1 & 2 & 1 & 0 & 0 & 14 \\
\hline Cyprus & 1 & 2 & 0 & 1 & 1 & 1 & 3 & 2 & 0 & 0 & 1 & 12 \\
\hline Lithuania & 0 & 0 & 1 & 0 & 5 & 1 & 0 & 2 & 2 & 0 & 0 & 11 \\
\hline Croatia & 2 & 1 & 1 & 2 & 1 & 0 & 0 & 1 & 2 & 0 & 0 & 10 \\
\hline Denmark & 1 & 1 & 1 & 1 & 0 & 2 & 1 & 1 & 0 & 1 & 0 & 9 \\
\hline Finland & 0 & 0 & 1 & 2 & 1 & 2 & 0 & 2 & 1 & 0 & 0 & 9 \\
\hline Romania & 0 & 0 & 0 & 0 & 0 & 1 & 2 & 0 & 0 & 1 & 0 & 6 \\
\hline Latvia & 0 & 0 & 1 & 0 & 0 & 2 & 1 & 0 & 0 & 1 & 0 & 5 \\
\hline Slovakia & 0 & 1 & 1 & 0 & 1 & 0 & 0 & 1 & 0 & 1 & 0 & 5 \\
\hline Estonia & 1 & 1 & 1 & 0 & 0 & 0 & 0 & 0 & 0 & 0 & 0 & 3 \\
\hline Slovenia & 0 & 0 & 0 & 0 & 1 & 0 & 0 & 1 & 1 & 0 & 0 & 3 \\
\hline $\begin{array}{l}\text { Czech } \\
\text { Republic }\end{array}$ & 0 & 0 & 0 & 0 & 0 & 0 & 0 & 1 & 1 & 0 & 0 & 2 \\
\hline Hungary & 0 & 0 & 0 & 0 & 0 & 0 & 0 & 1 & 0 & 1 & 0 & 2 \\
\hline Malta & 0 & 0 & 0 & 0 & 0 & 0 & 1 & 0 & 0 & 0 & 0 & 1 \\
\hline Bulgaria & 0 & 0 & 0 & 0 & 0 & 0 & 0 & 0 & 0 & 0 & 0 & 0 \\
\hline Luxembourg & 0 & 0 & 0 & 0 & 0 & 0 & 0 & 0 & 0 & 0 & 0 & 0 \\
\hline Total & 30 & 43 & 54 & 52 & 67 & 78 & 66 & 75 & 54 & 53 & 11 & 583 \\
\hline
\end{tabular}

The sum of the annual publications for each country in the time span 2010-2020 is greater than the number of publications examined in this bibliometric analysis. This occurs because, in the case of publications with co-authors from different countries, the publication count is referred to the country of each author. So, this means that the number of publications counted for each country is greater than the total number of publications actually produced. 


\section{National Energy Policy Analysis}

The main finding of bibliometric analysis (section 2) highlights that the three States with the greater number of publications in absolute terms on energy policy and Renewable Energy Sources (RES) are Germany, the United Kingdom and Spain.

Using the RES legal Europe database, it is possible to compare the energy policy of these States, in all three energy sectors: electricity (RES-E), heating/cooling (RES-H \& C) and transport (RES-T). Furthermore, with the consultation of the ministerial and governmental sites and the national energy plans, the energy policy of the three States has been analysed to highlight strengths and critical points.

\subsection{Germany}

According to the analysis of the International Energy Agency (IEA), the focus of German energy policy is the "Energiewende" plan, which literally means "energy reversal" or "energy revolution" - launched by the government in 2010 with the Energiekonzept document.

The Energiewende constitutes the German effort to reduce climate-damaging $\mathrm{CO}_{2}$ emissions without relying on nuclear energy. The aim is to lead Germany by 2022 to decarbonisation, through a system of State incentives, market bonuses and exemptions.

The German experience has been partly criticized and partly acclaimed. The most environmentalist authors believe that Germany is proof that an industrialized nation can eventually abandon fossil fuels without sacrificing the growth [19]-[21]. On the contrary, critics argue that German experience confirms that the transition to RES has a high cost for consumers and industry and does not automatically reduce carbon and $\mathrm{CO}_{2}$ emissions [22], [23].

This plan, which already provides a series of incentives, is accompanied by a complex regulation, generally indicated with the acronym EEG (Renewable Energy Act) and available on official site of Federal Ministry for Economic Affairs and Energy [24]. In particular, the political system initially envisaged a system of FIP (Feed-In Premium) and FIT (Feed-In Tariff) incentives. After the Germany Renewable Energy Act 2014 (EEG 2014), the FIT standard has become available only for Renewable Energy (RE) plants with a production capacity below $500 \mathrm{~kW}$, while public auctions claim its application also for larger plants. With the 2017 Renewable Energy Sources Act, public procurement procedures were introduced for onshore wind, offshore wind, solar energy and biomass projects, continuing towards the abandonment of FIT incentives. In other words, starting from 2017, companies that want to present projects for the development of clean energy plants will no longer be able to benefit from the government feed-in tariff rate, but they will have to bid in a public auction organized and monitored by the Federal Network Agency (Bundesnetzagentur). Successful projects will receive 20 -year contracts for the sale of electricity produced at the price they offered during the auction process. The results of this policy seem comfortable: in 2018 Germany is only 1.50 percentage points away from its target for 2020 , with a growth rate since 2004 of 10 percentage points.

\subsubsection{Electricity}

The "Stromeinspeisungsgesetz (StrEG - "Electricity Feed-in Law") was unanimously adopted by the German Bundestag in 1990. Revised several times during the 1990s, it is already expected in its original version that electricity obtained from renewable sources was introduced into the network or rather, "that electricity supplied the network" [25]. It is therefore not surprising that 
one of the main incentive mechanisms for electricity from renewable sources in Germany is FIT.

In general, the FIT systems are based on three key elements: guaranteed access to the network for producers of electricity generated by RES; long-term purchase contracts (generally 10 to 25 years) for the electricity produced; payments for each $\mathrm{kWh}$ of electricity generated, established on the basis of different logics.

In Germany, small RES-E systems up to $100 \mathrm{~kW}$ can benefit from the FIT tariff; however, the legislation provides that FIT incentive rates may also be provided for plants of different sizes, but the feed-in tariff is in this case reduced by $20 \%$ (EEG 2017) [24]. The tariff is reduced even if the plant manager receives other types of incentives, such as regional certificates.

Furthermore, in order to effectively obtain the incentive, the operator must face certain mandatory tasks including his plant registration on the Federal Network Agency, an agency based in Bonn that directly reports to the German Federal Ministry of Economy and Technology. The reason for this provision is evidently to guarantee the procedure transparency and the information accessibility (for example name, contact details of the operator, location of the power plant) of the plant that received the State subsidy from the German taxpayers. Moreover, the costs of the feed-in tariff regime are paid by the end consumers. The plant operator is therefore entitled to receive the FIT, for the amount of energy fed into the grid. The grid operator is obliged to purchase, transfer and distribute it [24].

Grants for electricity are based on a loan system. First of all, a financing and loan program is envisaged to support companies wishing to invest in offshore wind farms in the North Sea and Baltic Sea areas. Further financing programs are then envisaged for geothermal plants and for photovoltaic plants for which very low interest loans are provided.

However, according to the database, in Germany, the electricity from renewable sources is mainly supported through a FIP system. The Feed-in Premium can be fixed (i.e. at a constant level independent of market prices) or variable according to the evolution of market prices. In Germany, following the 2014 EEG reform, the fixed FIP regime has become mandatory for all new plants. It is determined through a bidding procedure, but there are still some projects where the value of the FIP is calculated as the difference between a fixed feed-in and the monthly market value of the electricity sold [24].

As regards the variable feed-in bonus, in 2017 this form of incentive that was granted by means of a tender (competition), is now no longer provided only for solar plants on the ground, but for all types of plant, from wind offshore to biomass plants.

Interestingly, biogas plant operators who have obtained support through a FIT or who have received an FIP may request a further support which can be received in addition and separately from the feed-in tariff or the market premium (EEG 2017).

\subsubsection{Heating and Cooling}

For the renewable energy use in residential and non-residential buildings, the market incentive program (MAP) is the reference point. For instance, The MAP provides a series of incentives and loans for solar energy and biomass-based heating systems and for heat pumps, to encourage the growth of the renewable energy use in the sector of heating and cooling of the buildings. In particular, it provides investment grants or repayment grants for low interest loans. 


\subsubsection{Transport}

According to RES legal, there are no forms of incentives for the renewable energy use in the transport sector. As of January 2016, all subsidies and tax exemptions for biofuels, including biomethane, were eliminated. Nonetheless, in the same year, an environmental bonus was introduced for the purchase of electric cars, Plug-in Hybrid Electric and Vehicles and hydrogen ones.

\subsection{United Kingdom}

According to "The UK's draft integrated National Energy and Climate Plan" since 1990, the United Kingdom "has reduced emissions by over $40 \%$ while growing the economy by more than two thirds". Indeed, according to data published by Eurostat, the United Kingdom has experienced a $10 \%$ growth in the production of renewable energy, but, in 2018 , it is still far from reaching its objectives.

Brexit should however change the dynamics of the renewable energy market in the United Kingdom, since the directives and regulations issued by Europe are no longer binding.

\subsubsection{Electricity}

In the United Kingdom, the generation of electricity from renewable sources is essentially supported by a FIT system and a variable FIP system, peculiar to the British system, also known as Contract for Difference (CfD). At the same time, it is supported by a tax regulation mechanism.

With regard to FIT, in Scotland, England and Wales, the plants admitted to the incentive are larger than those envisaged by Germany: the renewable energy plants admitted are those with a capacity of up to $5 \mathrm{MW}$, as long as they are duly accredited.

On the other hand, CfDs are new to the panorama of energy policies [26]. They are longterm contracts between a private low-carbon RES-E energy company and a State limited liability company (Low Carbon Contracts Company) [27], [28].

The CfD is based on a difference between the market price and an agreed "strike price". If an "exercise price" is higher than a market price, the CfD counterparty must pay the difference between the "exercise price" and the market price to the RES-E generator.

Since April 2017, the contracts for differences are the only financing and support systems for all new low $\mathrm{CO}_{2}$ emissions plants over $5 \mathrm{MW}$.

Furthermore, a tax regulation mechanism is provided, that is a tax for all plants that produce electricity from fossil fuels.

\subsubsection{Heating and cooling}

This energy sector is governed by two regulations that adjust the renewable heat incentive scheme (Reg. No. 2860 of 2001 and Reg. No. 928 of 2014) and by the Energy Act 2011.

The main financing instrument in this area is the Renewable Heat Incentive (RHI), an incentive to renewable domestic (domestic RHI) and non-domestic heat, for companies and businesses. The incentive practically allows the purchase at discounted rates of biomass boilers, solar water heating systems and some heat pumps. However, the success of this political initiative is uncertain [29], [30]. 


\subsubsection{Transport}

A quota system is provided for biofuels and, in particular, for biodiesel and bioethanol. In fact, the UK fuel suppliers for road and non-road vehicles (including inland waterway vessels) are required to meet a certain quota of biofuels in the total fuel supplied. There is a certification system to provide evidence of compliance with the political regime so briefly outlined.

\subsection{Spain}

According the International Energy Agency "Spain is a world leader in integration of different renewable energy and has built a robust electricity system with high shares of wind and solar PV. Cross-border connections are seen as essential to unlock Spain's renewable energy potential and its liquefied natural gas regasification capacity, the highest in the EU".

Indeed, if in 2018 Eurostat certified that Spain had not yet reached its target of $20 \%$ gross final energy consumption, the data published in 2019 by Red Eléctrica de España, national operator of the electricity system, were defined as a record: in fact, $6456 \mathrm{MW}$ of renewable energy were connected to the grid, with an increase of $6126 \mathrm{MW}$ more than the $330 \mathrm{~kW}$ of the previous year [31].

In fact, in 2019, Spain's energy policy has been profoundly changed and there have been numerous incentives from companies that deal with the development and management of energy activities from renewable sources all over the world and that are leading the nation towards the achievement of its goals for 2020.

For example, starting from 2017, Enel Green Power S.p.A. (EGP), in the wake of the "Integrated national plan for energy and climate" [32], has promoted a series of public auctions in Spain, following which three solar parks are under construction, respectively in Navalvillar, Valdecaballero and Castilblanco, for an installed capacity of $42 \mathrm{MW}$ each; meanwhile, in Totana a $85 \mathrm{MW}$ photovoltaic system is already in operation and, concerning the wind sector, 12 wind farms have been built for a total capacity of over $400 \mathrm{MW}$ in Aragon [32].

Overall, EGP has estimated that around 800 million euros have been invested in the development of renewable energy in Spain [32].

Moreover, the Spanish "Integrated National Energy and Climate Plan" envisages an ambitious project that aims to reduce dependence on non-renewable energy sources with an estimated saving of around $€ 75$ billion, as a result of the reduced use of sources of fossil combustion.

The Spanish government would like to achieve decarbonisation through massive investments that should reach the total amount of about 240 billion euros, with the closure of all coal plants that could be replaced thanks to the use of existing gas plants.

At the moment, the "Régimen Especial" was suspended in 2012 and replaced in 2014 by a new support scheme, named "Régimen Retributivo Específico": with this program the incentives are foreseen, awarded through tenders, for the construction of new renewable energy plants.

Premium rates or "specific remuneration scheme" are also provided, which are not technically defined as a support scheme, but as a complementary remuneration to allow renewable technologies to compete with traditional technologies in the energy market; on the other hand, the FIT incentive systems have recently been suspended. The RD n. 15/2018 contains, instead, some measures to ensure the implementation of the projects awarded in the 
context of the tenders and the obligation for the project developer to demonstrate the progress achieved in the implementation of the project.

Finally, it should be noted the reduction of electricity bills and the abolition of the so-called "Solar tax", which reduced the competitiveness of businesses and the purchasing power of consumers.

\subsubsection{Electricity}

In Spain, the incentive system for the development of renewable energy plants is essentially based on Regio Decrees, which have introduced a binary incentive system: Fixed TIF alongside FIP.

In other words, since 1998, renewable energy producers in Spain have the choice between a fixed tariff or a premium for technology in addition to the market price for electricity [33].

With the RD n. 661 of 2007, a first important change was foreseen, namely a variable definition system of the premium, which is adjusted every hour according to the market price.

With the RD n. 413 of 2014, a FIP incentive system based on a specific remuneration regime with offers in tenders was also provided. The system is valid for all types of energy, from wind to solar or photovoltaic.

In 2015, a new Royal Decree came into force which established a fixed tariff for selfconsumption plants lower than $10 \mathrm{~kW}$ and for the sea plants. However, after only three years, the RD n. 15 of 2018 replaced the new regime of 2015, in favour of a simplification of the procedures.

The Spanish FIT regime has been welcomed by scholars. While FITs could be perceived by consumers as an additional cost, the renewable energies cause a significant drop in prices in wholesale electricity markets [34]; furthermore, compared to the FIP models, fixed FIT incentives create greater investment security and lead to a distribution of renewable energy at lower costs [33].

\subsubsection{Heating and Cooling and Transport}

RES legal points out that no form of incentive is foreseen in Spain for cooling and heating, while for transport there is a quota system, that is similar to the UK one.

\section{Concluding Remarks among Renewable Policies of Analysed COUNTRIES}

The topic on research on policy mixes has received increasing attention from policy makers interested in accelerating socio-technical systems towards sustainability. Table 2 summarizes the support schemes of the States that have received strong attention from researchers in 2016 and 2017: Germany, UK and Spain.

The support schemes are subject to sudden changes due mainly to different political guidelines that influence the RES regulations in force. The duration of the support, on the other hand, refers to the plants that were financed in those years; i.e. if, for example, in Germany, by participating in the tender held in 2017, a photovoltaic system was built, the FIP incentive will be guaranteed for 20 years. 
TABLE 2. OVERVIEW OF NATIONAL SUPPORT SCHEMES FOR RES TECHNOLOGIES IN 2016 AND 2017

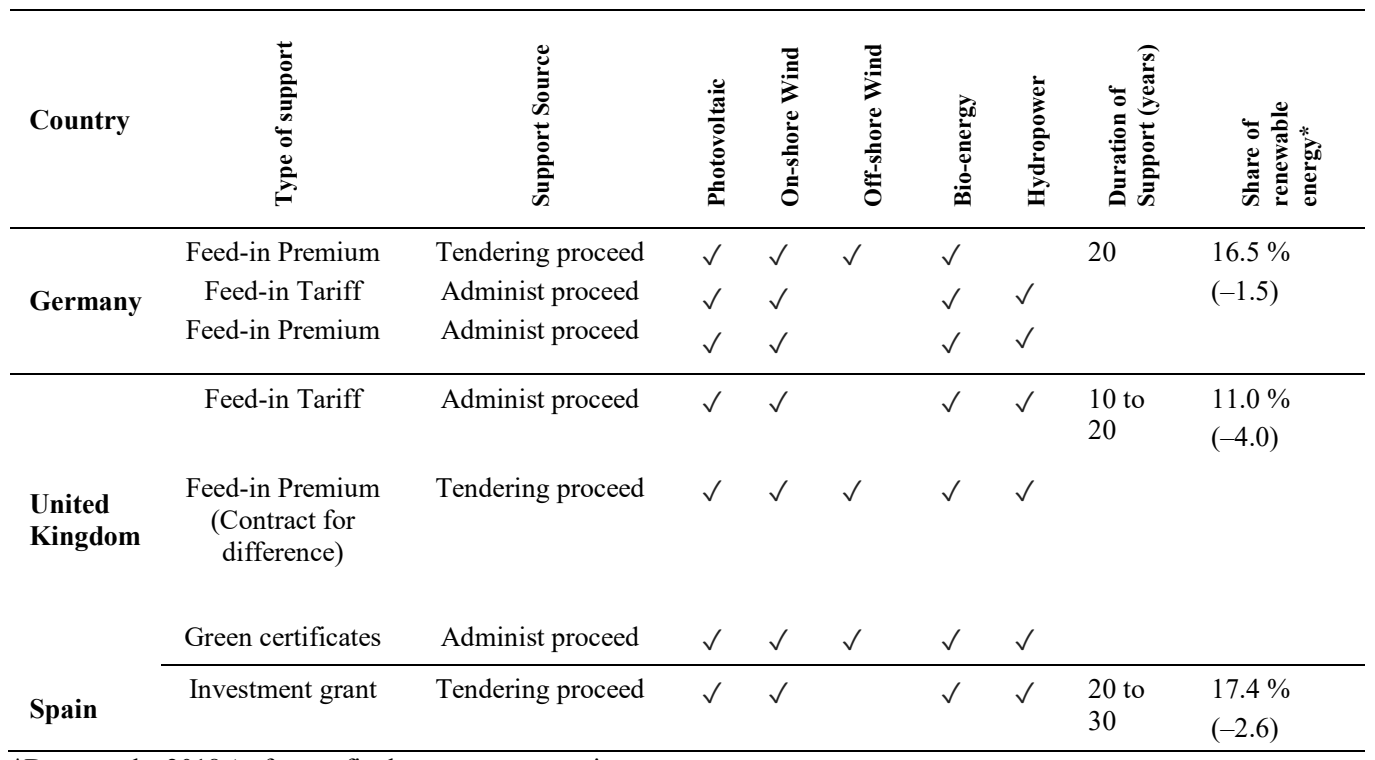

*Data are the $2018^{\wedge}$ of gross final energy consumption

The support sources, on the other hand, have been divided into tenders (the most used) and other administrative procedures of different typologies (for example for public auctions) which depend on the notice issued from time to time by the administration.

Therefore, in 2016-2017, the incentive tools used were mainly FIT and FIP.

In the UK, in addition to the particular type of FIP and CfD, green certificates were also used. Green certificates, increasingly popular in Europe, are particular types of incentives based on the mandatory rule according to which producers and importers of electricity generated by RES must annually introduce into the national electricity system a minimum share of electricity produced by plants that use renewable sources; basically, renewable electricity producers receive exchangeable certificates in proportion to the electricity they produce. The producer can then sell these certificates and receive additional revenue in addition to the price of energy [35].

Moreover, in Spain only investment grants were used during this period: in summary, the company, through tenders, can obtain a certain amount of money, to be used for the purchase of buildings, equipment, etc. useful to the production of RES.

Finally, a brief comparison between advantages and drawbacks of different incentives are summarized in Table 3, as it would help to understand the policy direction for other countries. 
TABLE 3. COMPARISON OF ADVANTAGES AND DISADVANTAGES FOR DIFFERENT INCENTIVE FORMS

\begin{tabular}{|c|c|c|}
\hline & Advantages & Disadvantages \\
\hline \multirow{3}{*}{$\begin{array}{l}\text { FIT (Feed-In } \\
\text { Tariff) }\end{array}$} & $\begin{array}{l}\text { - Low-risk support tool, since the payment, once } \\
\text { made, is no longer subject to the future trend of the } \\
\text { policy; }\end{array}$ & \multirow{3}{*}{$\begin{array}{l}\text { - All-inclusive tariffs are recognized based } \\
\text { on only the net energy fed into the grid and } \\
\text { therefore do not reward any self- consumed } \\
\text { production quota. }\end{array}$} \\
\hline & $\begin{array}{l}\text { - From the point of view of the grantor, the value of } \\
\text { the grant itself is known and does not, in principle, } \\
\text { foresee future liabilities; }\end{array}$ & \\
\hline & $\begin{array}{l}\text { - They can be applied to specific technologies and } \\
\text { markets or more broadly. }\end{array}$ & \\
\hline \multirow{3}{*}{$\begin{array}{l}\text { FIP (Feed-In } \\
\text { Premium) }\end{array}$} & $\begin{array}{l}\text { - They are flexible tools, in the sense that they are } \\
\text { gradually reduced or increased according to how the } \\
\text { reference technology and the related supply chain } \\
\text { evolve; }\end{array}$ & \multirow[t]{3}{*}{$\begin{array}{l}\text { - The incentive is for all the energy } \\
\text { produced regardless of its use (fed into the } \\
\text { grid or self-consumed immediately) } \\
\text { resulting in a complex control policy. }\end{array}$} \\
\hline & $\begin{array}{l}\text { - Credit for production stimulates an increase in the } \\
\text { production of clean energy; }\end{array}$ & \\
\hline & $\begin{array}{l}\text { - In addition to the incentive, the entrepreneur also } \\
\text { obtains the value of the energy fed into the network. }\end{array}$ & \\
\hline \multirow{2}{*}{$\begin{array}{l}\text { Green } \\
\text { Certificates }\end{array}$} & $\begin{array}{l}\text { - Discourage pollution by making production } \\
\text { companies already present in the area responsible and } \\
\text { encouraging them to change in more eco-sustainable } \\
\text { production; }\end{array}$ & \multirow[t]{2}{*}{$\begin{array}{l}\text { - The costs that the parties obliged to } \\
\text { purchase green certificates incur for the } \\
\text { fulfillment of the obligation itself. This } \\
\text { charge is indirectly charged to end } \\
\text { customers in the electricity prices. }\end{array}$} \\
\hline & $\begin{array}{l}\text { - Green certificates are recognized based on the net } \\
\text { energy produced and therefore also reward any self- } \\
\text { consumed production quota. }\end{array}$ & \\
\hline $\begin{array}{l}\text { Investment } \\
\text { Grant }\end{array}$ & $\begin{array}{l}\text { - Ensure companies producing from renewable } \\
\text { sources the sale of the entire amount of energy } \\
\text { produced, eliminating the risk and costs of unsold } \\
\text { energy shares. }\end{array}$ & $\begin{array}{l}\text { - Public auctions are easily subject to } \\
\text { infiltration by organized crime. }\end{array}$ \\
\hline
\end{tabular}

\section{IMPLICATIONS}

In principle, the same forms of incentives have been used in all the aforementioned three States. FIP and FIT are the most used ones, and although a more atypical regime like CfD has been envisaged in the UK, they are nothing more than premium feed-in forms. In general, there was no diversified incentive in relation to the type of RES plant to be built, or in relation to the territorial conformation and therefore to the most available natural resources, not only between but also within the same States. For example, in Germany the landers closest to the sea could receive a greater subsidy for the construction of marine hydroelectric plants, while in the northernmost regions of the UK the construction of wind farms could be more encouraged.

This diversification, depending on the geological conformation of the State, has proved successful in other EU States, such as Denmark, which has not only achieved its objectives, but has even exceeded them [36]. Although Denmark ranks among the States that have produced the least scientific publications on energy policy, in 2018 it has already reached a share higher than its 2020 national target and, in 2019, has produced almost half of its energy. According to Wind-Europe [37] on March 9, 2020, compared to other member States, Denmark produced $108 \%$ of wind energy, of which $70 \%$ onshore wind energy and $38 \%$ 
offshore. The second place, assigned to Germany, saw the production of only $50 \%$ of wind energy, divided into $40 \%$ onshore and $10 \%$ offshore.

The FIP incentives provided by the Danish energy policy have also involved the construction of numerous windmills for the production of electricity and multiple wind turbines, which are financed with a separate state fund and through premium feeds which can be accessed through tenders, launched by the Danish Ministry of Energy, Utilities and Climate; the ministry also provides guarantees for loans from local wind and solar plant owners associations. An example of a tender is that of 2012 for the construction of a $400 \mathrm{MW}$ offshore wind farm off Anholt.

Lastly, the Danish example shows that it does not seem to be a correlation between rate of publication and the results achieved by the analysed countries. This topic will be analysed in following research.

\section{Conclusions}

In this work, after carrying out a bibliometric analysis of the publications-published by the Member States of the European Union in the field of energy policies, the energy policies of the most prolific states are analysed from the point of view of the publications on Scopus. The considered countries are Germany, UK and Spain. Therefore, the related energy policies are specifically analysed based on: the RES legal database, the various institutional sites and the energy plans presented by the same nations in compliance with the European directives on renewable energy. The main focus is on incentives, the most functional tool for implementing RES systems.

At this point, it has been noted that the three countries have many features in common and, above all, a large use of FIT and FIP incentives. However, these are generally envisaged for all energy sectors, regardless of the geological conformation of the territory. In fact, Germany, Spain and the UK have the possibility to incentivize different forms of energy. For example, the United Kingdom could focus more on the development of hydroelectric power plants and Spain take more advantage of the sun's energy. Another country, Denmark, which have focused on the development of the RE energy most suitable for the conformation of the territory have in fact achieved the greater results, quickly reaching and even exceeding the objective set by the European Union, although it has not demonstrated a high level of research and scientific dissemination on energy policy.

Even Luxembourg has not focused on scientific dissemination, but the uniformity in the management of energy policies at a central level has promoted proximity to citizens and companies of the Public Administration, allowing for a greater response between supply and demand.

Over the years, Luxembourg has achieved exponential growth in energy terms, like Denmark. As the sample States, it has focused heavily on various forms of incentives.

Therefore, to date, combining FIT and FIP would seem to be the winning solution for the States that want to aim for sustainable energy development. Moreover, the advantages and disadvantages of the support tools would be offset if the States proposed all these forms of incentive together. 


\section{REFERENCES}

[1] Erdiwansyah Mamat R., Sani M. S. M., Sudhakar K. Renewable energy in Southeast Asia: Policies and recommendations. Science of The Total Environment 2019:670:1095-1102. https://doi.org/10.1016/j.scitotenv.2019.03.273

[2] Vural G. Renewable and non-renewable energy-growth nexus: A panel data application for the selected Sub-Saharan African countries. Resources Policy 2020:65:101568. https://doi.org/10.1016/j.resourpol.2019.101568

[3] Panwar N. L., Kaushik S. C., Kothari S. Role of renewable energy sources in environmental protection: A review. Renewable and Sustainable Energy Reviews 2011:15(3):1513-1524. https://doi.org/10.1016/j.rser.2010.11.037

[4] Waheed R., Sarwar S., Wei C. The survey of economic growth, energy consumption and carbon emission. Energy Reports 2019:5:1103-1115. https://doi.org/10.1016/j.egyr.2019.07.006

[5] Blumberga D., et al. Energy, Bioeconomy, Climate Changes and Environment Nexus. Environmental and Climate Technologies 2019:23(3):370-392. https://doi.org/10.2478/rtuect-2019-0102

[6] Cucchiella F., D’Adamo I., Gastaldi M. Future Trajectories of Renewable Energy Consumption in the European Union. Resources 2018:7(1):10. https://doi.org/10.3390/resources7010010

[7] Avotniece Z., Klavins M., Rodinovs V. Changes of Extreme Climate Events in Latvia. Environmental and Climate Technologies 2012:9(1):4-11. https://doi.org/10.2478/v10145-012-0010-1

[8] Annibaldi V., Cucchiella F., Rotilio M. A Sustainable Solution for Energy Efficiency in Italian Climatic Contexts. Energies 2020:13(11). https://doi.org/10.3390/en13112817

[9] Solorio I., Bocquillon P. EU renewable energy policy: a brief overview of its history and evolution. $A$ Guide to EU Renewable Energy Policy 2017:23-42. https://doi.org/10.4337/9781783471560.00011

[10] Bull S. R. Renewable energy today and tomorrow. Proceedings of the IEEE 2001:89(8):1216-26. https://doi.org/10.1109/5.940290

[11] Ntanos S., et al. Renewable Energy and Economic Growth: Evidence from European Countries. Sustainability 2018:10(8):2626. https://doi.org/10.3390/su10082626

[12] Cucchiella F., D'Adamo I. Technical and economic analysis of biomethane: A focus on the role of subsidies. Energy Conversion and Management 2016:119:338-351. https://doi.org/10.1016/j.enconman.2016.04.058

[13] Cucchiella F., D'Adamo I., Gastaldi M. Modeling optimal investments with portfolio analysis in electricity markets. Energy Education Science and Technology Part A: Energy Science and Research 2012:30(1):673-692.

[14] Scarlat N., Dallemand J.-F., Monforti-Ferrario F., Banja M., Motola V. Renewable energy policy framework and bioenergy contribution in the European Union - An overview from National Renewable Energy Action Plans and Progress Reports. Renewable and Sustainable Energy Reviews 2015:51:969-85. https://doi.org/10.1016/j.rser.2015.06.062

[15] Eikeland P. O., Skjærseth J. B. The Politics of Low-Carbon Innovation. The EU Strategic Energy Technology Plan. Palgrave Macmillan, Cham, 2020. https://doi.org/10.1007/978-3-030-17913-7

[16] Annibaldi V., Cucchiella F., De Berardinis P., Gastaldi M., Rotilio M. An integrated sustainable and profitable approach of energy efficiency in heritage buildings. Journal of Cleaner Production 2020:251:119516. https://doi.org/10.1016/j.jclepro.2019.119516

[17] Bassi A. M. Moving Towards Integrated Policy Formulation and Evaluation: The Green Economy Model. Environmental and Climate Technologies 2015:16(1):5-19. https://doi.org/10.1515/rtuect-2015-0009

[18] Aboltins R., Blumberga D. Key Factors for Successful Implementation of Energy Efficiency Policy Instruments: A Theoretical Study and the Case of Latvia. Environmental and Climate Technologies 2019:23(2):187-206. https://doi.org/10.2478/rtuect-2019-0063

[19] Bechberger M., Reiche D. Renewable energy policy in Germany: pioneering and exemplary regulations. Energy for Sustainable Development 2004:8(1):47-57. https://doi.org/10.1016/s0973-0826(08)60390-7

[20] Wüstenhagen R., Bilharz M. Green energy market development in Germany: effective public policy and emerging customer demand. Energy Policy 2006:34(13):1681-1696. https://doi.org/10.1016/j.enpol.2004.07.013

[21] Michelsen C. C., Madlener R. Switching from fossil fuel to renewables in residential heating systems: An empirical study of homeowners' decisions in Germany. Energy Policy 2016:89:95-105. https://doi.org/10.1016/j.enpol.2015.11.018

[22] Nordensvärd J., Urban F. The stuttering energy transition in Germany: Wind energy policy and feed-in tariff lock-in. Energy Policy 2015:82:156-165. https://doi.org/10.1016/j.enpol.2015.03.009

[23] Wang Q., Zhou Y. Uncovering embodied $\mathrm{CO}_{2}$ flows via North-North trade - A case study of US-Germany trade. Science of The Total Environment 2019:691:943-959. https://doi.org/10.1016/j.scitotenv.2019.07.171

[24] Federal ministry for economic affairs and energy [Online]. [Accessed 24.10.2020]. Available at: https://www.bmwi.de

[25] Büsgen U., Dürrschmidt W. The expansion of electricity generation from renewable energies in Germany. Energy Policy 2009:37(7):2536-45. https://doi.org/10.1016/j.enpol.2008.10.048

[26] Onifade T. T. Hybrid renewable energy support policy in the power sector: The contracts for difference and capacity market case study. Energy Policy 2016:95:390-401. https://doi.org/10.1016/j.enpol.2016.05.020 
[27] Kozlov N. Contracts for difference: risks faced by generators under the new renewables support scheme in the UK. The Journal of World Energy Law \& Business 2014:7(3):282-286. https://doi.org/10.1093/jwelb/jwu016

[28] Palacio S. M. Predicting collusive patterns in a liberalized electricity market with mandatory auctions of forward contracts. Energy Policy 2020:139:11131. https://doi.org/10.1016/j.enpol.2020.111311

[29] Chaudry M., et al. Uncertainties in decarbonising heat in the UK. Energy Policy 2015:87:623-40. https://doi.org/10.1016/j.enpol.2015.07.019

[30] Mavromatidis G., et al. Ten questions concerning modeling of distributed multi-energy systems. Building and Environment 2019:165:106372. https://doi.org/10.1016/j.buildenv.2019.106372

[31] Red Electrica de Espana [Online]. [Accessed 24.10.2020]. Available at: https://www.ree.es/es

[32] European Union. The 2021-2030 Integrated National Energy and Climate Plan. April 2020. [Online]. [Accessed 24.10.2020]. Available at: https:/ec.europa.eu/energy/sites/ener/files/documents/ro_final_necp_main_en.pdf

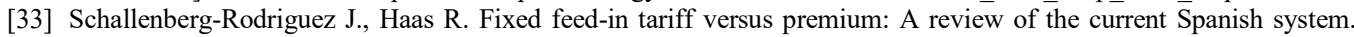
Renewable and Sustainable Energy Reviews 2012:16(1):293-305. https://doi.org/10.1016/j.rser.2011.07.155

[34] Gallego-Castillo C., Victoria M. Cost-free feed-in tariffs for renewable energy deployment in Spain. Renewable Energy 2015:81:411-420. https://doi.org/10.1016/j.renene.2015.03.052

[35] Jensen S. G., Skytte K. Interactions between the power and green certificate markets. Energy Policy 2002:30(5):425435. https://doi.org/10.1016/s0301-4215(01)00111-2

[36] Swain R. B., Karimu A. Renewable electricity and sustainable development goals in the EU. World Development 2020:125:104693. https://doi.org/10.1016/j.worlddev.2019.104693

[37] Wind Europe. Wind power share in the country's electricity mix. [Online]. [Accessed 12.04.2020]. Available: https://windeurope.org/about-wind/daily-wind/top-countries 